\title{
PELATIHAN PENGEMBANGAN METODE PEMBELAJARAN UNTUK MENINGKATKAN KETERAMPILAN SOSIAL ANAK
}

\author{
Oleh: \\ Muthmainnah, Ika Budi Maryatun, Nur Cholimah \\ diwan_nafil@yahoo.co.id; budi ika@yahoo.com; nurcholimah halim@yahoo.co.id \\ PAUD FIP Universitas Negeri Yogyakarta
}

\begin{abstract}
Abstrak
Program ini bertujuan untuk meningkatkan pengetahuan dan kreativitas guru TK dalam mengembangkan metode pembelajaran untuk meningkatkan keterampilan sosial anak. Khalayak sasaran dalam program ini adalah 65 guru TK di wilayah Kecamatan Adimulyo Kebumen. Kegiatan ini dilaksanakan dengan metode ceramah, tanya jawab, simulasi permainan, pemberian tugas dan diskusi, serta presentasi. Program ini dapat meningkatkan pengetahuan guru tentang metode pembelajaran untuk meningkatkan keterampilan sosial anak TK. Hal ini dapat dilihat dari hasil evaluasi penyelenggaraaan kegiatan dan evaluasi pengembangan metode pembelajaran yang telah mencapai indikator keberhasilan melebihi $80 \%$. Berdasarkan hasil penyebaran skala tentang penyelenggaraan kegiatan dapat disimpulkan bahwa $93 \%$ guru TK (61 peserta) merasa materi yang disampaikan sesuai dan bermanfaat. Hal ini dapat dilihat dari hasil pengisian skala yang rata-rata memperoleh skor 3 (kriteria baik). Untuk hasil pemberian tugas, enam kelompokmemperoleh kriteria baik dalam merancang kegiatan pembelajaran hari memasak, proyek, dan permainan kooperatif.
\end{abstract}

Kata Kunci: Pengembangan, metode pembelajaran, keterampilan sosial

\section{Abstract}

This service program has purpose of improving the Kindergarten teacher's and creativeness in developing learning methods to improve children soscial skliss. The participants of this program is 65 Kindergarten teacher's in adimulyo Kebumen. The activity includes the methods of lecturing, questions and answer, simulation games, giving assigment and discussion, and presentation. This program can improve the teacher's knowledge about learning methode to improve Kindergarten children 's social skills. This can be seen from the result of the program evaluation and the evaluation of developing learning methods that have reached achievement indicators more than $80 \%$. Based on the scale survey, it can be inferred that $93 \%$ think that the program materials delivered are suitable and beneficial. This is seen from the scale survey result that reach in average the score 3 (good criteria). For the result of giving assigment, six groups gained good criteria in designing learning activities of cooking day, project, and cooperative games.

Keywords: developing, learning method, social skill

\section{PENDAHULUAN}

Keterampilan sosial (soft skill) merupakan keterampilan individu yang merujuk pada sekumpulan karakteristik kepribadian, daya tarik sosial, kemampuan berbahasa, kebiasaan pribadi, kepekaan/kepedulian, serta optimisme. Keterampilan sosial meliputi: a) keterampilan intrapersonal seperti kualitas pribadi (tanggungjawab, kesadaran diri, kepercayaan diri, kemampuan bersosialisasi, pengendalian diri, dan kejujuran; serta (b) keterampilan 
interpersonal seperti keterlibatan sebagai anggota kelompok, kemampuannegosiasi, manajemen konflik dan kerjasama. Keterampilan sosial juga meliputi kemampuan mengenali diri, mengenali emosi, empati, simpati, berbagi, negosiasi/kompromi, asertif, kerjasama, dan bersaing secara sportif. Keterampilan sosial (soft skill) melengkapi hard skills (wikipedia), sehingga keduanya perlu dikembangkan secara proporsional.

Berdasarkan wawancara dengan guru di beberapa TK di daerah kecamatan Adimulyo Kebumen, kegiatan anak lebih banyak didominasi dengan penyelesaian Lembar Kegiatan Anak (LKA). Wawancara yang dilakukan pengabdi dengan beberapa guru yang mengungkapkan bahwa permasalahan lain yang muncul yaitu keterbatasan pengetahuan guru untuk mengembangkan metode pembelajaran, khususnya untuk meningkatkan keterampilan sosial anak. Keterampilan sosial pada umumnya distimulasi dan diasah dengan diselipkan dalam kegiatan pembelajaran, artinya belum ada metode pembelajaran khusus yang diimplementasikan untuk peningkatan keterampilan sosial anak. Metode pembelajaran yang digunakan pun terbatas pada kegiatan pemberian tugas dan bercerita yang pelaksanannya tidak rutin dan lebih berpusat pada guru (teacher centered). Sementara peran serta orang tua belum dilibatkan secara aktif. Padahal keterlibatan aktif orang tua dalam pembelajaran mampu mendorong adanya peningkatan kualitas pembelajaran.

Salah satu upaya untuk mewujudkan peningkatan keterampilan sosial anak yaitu melalui metode pembelajaran cooking day/fun cooking (hari memasak), project (proyek), market day (hari pasar), career day (hari karir) dan permainan kooperatif. Melalui hari memasak, proyek, hari pasar, hai karir dan permainan kooperatif yang dilakukan secara intensif, diharapkan dapat meningkatkan keterampilan sosial anak sekaligus memberikan variasi kegiatan yang membangkitkan keaktifan, minat dan partisipasi anak serta orang tua dalam pembelajaran.

\section{Identifikasi Masalah}

1. Kegiatan di TK lebih dominan dengan menyelesaikan LKA (Lembar Kegiatan Anak) yang lebih bersifat individual, sehingga keterampilan sosial kurang terasah dengan baik.

2. Pengembangan keterampilan sosial hanya diselipkan melalui kegiatan pembelajaran.

3. Metode pembelajaran yang digunakan di TK belum variatif, lebih banyak pada kegiatan pemberian tugas dan bercerita.

4. Keterbatasan pengetahuan guru untuk mengembangkan metode pembelajaran, khususnya untuk meningkatkan keterampilan sosial anak.

\section{Perumusan Masalah}

Bagaimana meningkatkan pengetahuan dan kreativitas guru TK dalam mengembangkan metode pembelajaran untuk meningkatkan keterampilan sosial anak?

\section{Tujuan Kegiatan}

Adapun tujuan yang akan dicapai dalam kegiatan ini adalah meningkatkan pengetahuan dan mengembangkan kreativitas guru-guru TK dalam mengembangkan metode pembelajaran untuk meningkatkan keterampilan sosial anak.

\section{Metode Pembelajaran}

Sagala S. (2003) mengemukakan bahwa metode pembelajaran adalah cara yang digunakan guru dalam mengorganisasikan kelas pada umumnya atau dalam menyajikan bahan pelajaran pada khususnya. Surakhmad W (1979) juga mengemukakan bahwa metode adalah cara yang di dalam fungsinya merupakan 
alat untuk mencapai suatu tujuan. Majid (2005) mengungkapkan bahwa metode pembelajaran apapun yang digunakan oleh guru, sebaiknya mampu mengakomodasi prinsip-prinsip pembelajaran seperti pembelajaran yang berpusat pada anak didik (student oriented). Guru sebaiknya memandang anak didik sebagai pribadi yang unik, maka suatu kekeliruan jika guru memperlakukan mereka secara sama. Selain itu, agar proses belajar menyenangkan guru harus menyediakan kesempatan kepada anak didik untuk melakukan apa yang dipelajarinya, sehingga anak memperoleh pengalaman nyata. Guru pun perlu mengembangkan kemampuan sosial. Proses pembelajaran dan pendidikan selain sebagai wahana untuk memperoleh pengetahuan, juga sebagai sarana untuk berinteraksi sosial (learning to live together). Di sisi lain, guru juga perlu mengembangkan rsa ingin tahu dan imajinasi anak agar mampu berpikir kritis dan kreatif dalam menyelesaikan masalah.

\section{Alternatif Metode Pembelajaran untuk Mengembangkan Keterampilan Sosial}

a. Hari memasak (cooking day atau fun cooking)

Yaitu kegiatan yang dirancang guru dalam membekali anak melalui kegiatan memasak makanan sederhana sesuai kemampuan anak. Melalui kegiatan memasak dapat menumbuhkan dan mengembangkan konsep diri bahwa "aku bisa", sehingga anak akan lebih percaya diri dan bertanggung jawab. Adapun makanan sederhana yang dapat dibuat anak misalnya gethuk, roti bakar, sandwich, bola-bola coklat, puding, jus buah, sate buah, sirup, es krim dan sebagainya.

b. Proyek (project)

Metode proyek berasal dari gagasan John Dewey tentang konsep "learning by doing". Metodeproyekmerupakansuatucarapem berianpengalamanbelajardenganmemb erianakpermasalahanataupersoalanseha ri-hari yang harus dipecahkan secara berkelompok (Moeslichatoen, 2004). Manfaat metode proyek diantaranya yaitu memberikan pengalaman menyelesaikan masalah secara berkelompok (kerjasama), memberikanpeluangbagianakuntukme wujudkandayakreativitasnya, dan mendorong munculnya pribadi yang kooperatif/memiliki sikap positif (mandiri, tanggung jawab, saling membantu dan saling menghargai). Kegiatan proyek yang dapat dilakukan oleh anak seperti: menyiapkan hidangan tamu, membuat pohon tiruan, membuat pesawat, proyek bumi antariksa, proyek hutan belantara, proyek 17 Agustus, proyek menanam bunga di kebun sekolah, membuat binatang laut tiruan, membuat pulau menggunakan playdough dan sebagainya.

c. Hari karir (career day)

Yaitu kegiatan mengenalkan anak pada cita-cita atau impian di masa depan. Hal ini dapat menumbuhkan semangat anak untuk selalu belajar, percaya diri, dan menghargai profesi atau pekerjaan orang lain. Harir karir dapat dilakukan dengan memintaanak menggambar bebas tentang cita-citanya kemudian menunjukkan pada temantemanya di kelas, mengunjungi suatu tempat yang menunjukkan profesi seperti pengusaha tempe, kantor pos, puskesmas dan profesi lainnya. Selain itu dapat juga dilakukan dengan mengundang narasumber ke PAUD untuk menceritakan profesinya, serta pentas dengan menggunakan baju yang menunjukkan ciri khas profesinya kemudian bercerita di depan temantemannya.

d. Hari pasar (market day)

Yaitu kegiatanjual beli barangbarang hasil karya anak untuk melatih jiwa kewirausahaan, kejujuran, kemampuan negosiasi, kemampuan komunikasi, dan melatih anak dalam 
berinteraksi dengan orang lain. Hari pasar dapat dilakukan dengan mengunjungi pasar dan melakukan transaksi jual beli sederhana, anak menjual barang di sekolah kemudian orang tua, guru atau warga sekitar sebagai pembeli.

e. Permainan kooperatif

Yaitu permainan yang dilakukan secara berkelompok dan bertujuan untuk melatih komunikasi dan kerjasama. Permainan kooperatif yang dapat dilakukan anak seperti: menjala ikan, ambilkan sepatuku, estafet bendera, pesan berantai, gambar berantai, dan permainan kooperatif lainnya.

\section{Keterampilan Sosial}

Keterampilan sosial berasal dari kata terampil dan sosial, artinya mengajarkan kemampuan berinteraksi dengan orang lain. Keterampilan sosial yaitu perilaku spesifik, inisiatif, mengarahkan pada kemampuan sosial yang diharapkan sebagai bentuk perilaku seseorang (Merrel). Apabila keterampilan sosial seseorang tidak terasah dengan baik, maka dapat menyebabkan kesulitan perilaku di sekolah, munculnya kenakalan, hambatan emosional, bullying, agresivitas, masalah dalam hubungan interpersonal, kegagalan akademik, dan bahkan depresi.

Keterampilan sosial yang perlu diasah diantaranya yaitu kemampuan berkomunikasi, menjalin hubungan dengan orang lain, menghargai diri sendiri dan orang lain, mendengarkan pendapat atau keluhan dari orang lain, memberi atau menerima masukan, berperilaku sesuai norma dan aturan dan sebagainya. Individu yang kurang memiliki keterampilan sosial ditandai dengan rendahnya kualitas dalam berinteraksi dengan orang lain, mempunyai kecemasan yang tinggi dan kurang mempunyai pengalaman sosial sehingga sering merasa kesepian, tidak bahagia, menarik diri dan agresif.

Sebagian orang tua memiliki anggapan bahwa keterampilan sosial kurang penting untuk diperhatikan dalam kehidupan. Orang tua mengangggap bahwa anak akan belajar dengan sendirinya untuk berinteraksi secara baik dengan teman, saudara atau orang lain. Padahal anak yang kurang memiliki keterampilan sosial, umumnya akan mengalami kesulitan dalam menjalin hubungan yang positif dengan lingkungannya, atau bahkan ditolak atau diabaikan oleh lingkungannya.

\section{Aspek dalam Keterampilan Sosial}

Terdapat beberapa aspek dalam keterampilan sosial yang perlu diasah diantaranya yaitu: Keterampilan sosial meliputi: a) keterampilan intrapersonal seperti kualitas pribadi (tanggungjawab, kesadaran diri, kepercayaan diri, kemampuanbersosialisasi, pengendalian diri, dankejujuran; serta (b) keterampilan interpersonal seperti keterlibatan sebagaianggotakelompok,

kemampuannegosiasi, manajemen konflik dan kerjasama. Keterampilan sosial juga meliputi kemampuan mengenali diri, mengenali emosi, empati, simpati, berbagi, negosiasi/kompromi, asertif, kerjasama, dan bersaing secara sportif. Keterampilan sosial (soft skill) melengkapi hard skills (wikipedia), sehingga keduanya perlu dikembangkan secara proporsional.

Dalam pembelajaran di TK, aspek yang terkait dengan pengembangan keterampilan sosial yaitu aspek sosial emosional. Adapun pembelajaran mengacu denganTingkat Pencapaian Perkembangan (TPP) yaitu: bersikap kooperatif dengan teman, menunjukkansikaptoleran, mengekspresikan emosi sesuai dengan kondisi, mengenal tatakrama dan sopan santun sesuai dengan nilai sosial budaya setempat, memahami peraturan dan disiplin, menunjukkan rasa empati, memiliki sikap gigih (tidak mudah menyerah), bangga terhadap hasil karya sendiri, dan menghargai keunggulan orang lain. Perkembangan sosial emosional juga mencakup sikap tenggang rasa, peduli, saling menghargai, saling menghormati, 
bekerjasama, empati dan lain sebagainya. Berkaitan dengan perkembangan sosial anak, pada dasarnya setiap anak akan memerlukan bantuan orang lain dan akan hidup menjadi manusia sosial. Namun dalam kenyataannya masih banyak anak yang belum dapat bersosialisasi dengan orang lain, sehingga anak perlu dilatih agar memiliki keterampilan sosial pada dirinya. Keterampilan sosial pada anak dapat dikembangkan melalui berbagai metode di antaranya: permainan, metode bercerita, metode tanya jawab, metode karyawisata, metode bermain peran, hari memasak, proyek, hari karir, dan sebagainya.

\section{Khalayak Sasaran}

Khalayak sasaran yang dituju dalam pelatihan ini adalah guru-guru TK di wilayah Kecamatan Adimulyo Kebumen yang berjumlah 65 orang.

\section{Metode Kegiatan}

Kegiatan dilaksanakan dengan metodeceramah dan tanya jawab, simulasi permainan,pemberian tugas, diskusi, danpresentasi. Metode ceramah digunakan untuk memberikan pemahaman pada peserta tentang pengembangan metode pembelajaran untuk meningkakan keterampilan sosial anak TK, yang meliputi pengetahuan tentang hari memasak, proyek, hari pasar, hari karir, dan permainan kooperatif. Metode tanya jawab digunakan untuk memberikan kesempatan pada peserta apabila ada hal yang ingin ditanyakan dan melibatkan peserta untk aktif dalam mengikuti materi. Selanjutnya dilakukan simulasi dari metode permainan kooperatif yang belum pernah dipraktekkan guru-guru di TK nya, sehingga dapat menambah khasanah ragam permainan untuk anak.

Kegiatan simulasi permainan dilakukan di dalam kelas dengan guru sebagai peserta permainan yang dipandu oleh pengabdi. Untuk metode pemberian tugas, pengabdi membagi peserta menjadi enam kelompok dan diberikan tugas untuk merancang kegiatan pengembangan keterampilan sosial anak di TK melalui kegiatan permainan kooperatif, proyek, dan cooking day (hari memasak). Pemberian tugas ini diselesaikan kelompok melalui metode diskusi yang bertujuan untuk memperkuat pemahaman peserta selama dan setelah ceramah dan mengembangkan ide serta kreatifitas peserta. Hasil diskusi kelompok kemudian dipresentasikan di depan kelas untuk diberikan feed back oleh pengabdi maupun peserta kelompok lainnya.

\section{Evaluasi Kegiatan}

Evaluasi yang digunakan dalam program ini yaitu evaluasi program dan evaluasi kemampuan guru. Untuk evaluasi penyelenggaraan digunakan skala yang diisi oleh peserta (format evaluasi terlampir). Indikator keberhasilan penyelenggaraan program ini yaitu apabila hasil skala memiliki signifikansi $80 \%$, artinya dari $80 \%$ peserta pelatihan menyatakan respon positif (materi jelas, sesuai dan bermanfaat) dalam penyelenggaraan program. Selain itu, indikator keberhasilan untuk evaluasi kemampuan guru dalam pengembangan metode pembelajaran untuk meningkatkan keterampilan sosial sebesar $80 \%$, artinya $80 \%$ peserta mampu mengembangkan metode pembelajaran yang mengarah pada keterampilan sosial anak yang variatif dan kreatif.

\section{Hasil Pelaksanaan Kegiatan}

Pelatihan pengembangan metode pembelajaran untuk meningkatkan keterampilan sosial anak TK dilaksanakan dengan melibatkan guru-guru TK di wilayah Kecamatan Adimulyo Kebumen yang berjumlah 65 peserta. Kegiatan ini dilakukan dengan metode ceramah, tanya jawab, simulasi permainan, pemberian tugas dan diskusi, serta presentasi. Berdasarkan hasil penyebaran skala tentang penyelenggaraan kegiatan dapat disimpulkan bahwa $93 \%$ guru TK, yaitu sebanyak 61 peserta menyatakan materi yang disampaikan bermanfaat dan sesuai 
dengan kebutuhan. Hal ini dapat dilihat dari hasil pengisian skala yang rata-rata memperoleh skor 3 (kriteria baik). Adapun format evaluasi terlampir. Berdasarkan rubrik penilaian dalam diskusipengembangan metode pembelajaran untuk meningkatkan keterampilan sosial anak TK, enam kelompok mencapai kriteria baik dalam merancang kegiatan pembelajaran.

\section{Pembahasan}

Pada awalnya anak masih bersifat egosentris, namun lingkungan dapat mengarahkan anak menjadi sosiosentris. Lingkungan yang dimaksud diantaranya sekolah. Guru di sekolah perlu mengembangkan kemampuan sosial yang dapat menambah dan memperkuat pengalaman sosial anak. Hal ini diperkuat oleh pendapat Majid (2005) yang mengungkapkan bahwa proses pembelajaran dan pendidikan dapat diberikan sebagai wahana untuk memperoleh pengetahuan, juga sebagai sarana untuk berinteraksi sosial (learning to live together). Proses pembelajaran di sekolah dapat dioptimalkan melalui pengembangan metode pembelajaran yang variatif dan inovatif. Hal ini bertujuan agar anak lebih antusias dalam mengikuti kegiatan dan pembelajaran lebih menyenangkan. Salah satu pembelajaran yang perlu dipertimbangkan yaitu pembelajaran yang mengarah pada peningkatan keterampilan sosial anak TK. Apabila keterampilan sosial seseorang tidak terasah dengan baik, maka dapat menyebabkan kesulitan perilaku di sekolah, hambatan emosional, masalah dalam hubungan interpersonal, dan dampak psikologis lainnya.

Metode pembelajaran yang diterapkan diharapkan dapat meningkatkan keterampilan sosial anak diantaranya melalui kegiatan seperti hari memasak, proyek, hari karir, hari pasar dan permainan kooperatif. Melalui kegiatankegiatan tersebut, anak dilatih untuk berkomunikasi, kompromi, mau mencoba, bekerjasama, tanggung jawab sesuai dengan tugas yang diberikan, sportif dan jujur. Hal ini sesuai dengan tujuan pengembangan keterampilan nasional yaitu berinteraksi dengan orang lain dalam konteks sosial dengan cara-cara yang khusus yang dapat diterima secara sosial maupun nilai-nilai.

\section{Berdasarkan rancangan peserta} dalam pengembangan metode pembelajaran untuk meningkatkan keterampilan sosial, anak-anak dilatih untuk percaya diri, mau berkomunikasi, mau berbagi, bertanggung jawab dengan tugasnya, dan mau bekerjasama dengan teman. Hal ini dapat dilihat melalui rancangan pada kegiatan hari memasak, anak dilatih untuk membuat donat, roti bekal sekolah, pecel, telur ceplok, teh manis dan es sirup, dan sate pepaya. Pada kegiatan proyek, anak diajak untuk menyelesaikan proyek ulang tahun, proyek makan bersama, proyek menata kelas, proyek menata kebun dan halaman sekolah serta proyek membuat akuarium buatan. Selain itu, pada pada permainan kooperatif, anak diajak melakukan permainan menjala ikan, mencari harta karun, tebak warna, pesan berantai, estafet kalung gembira, dan bintang beralih.

Melalui kegiatan memasak dapat menumbuhkan dan mengembangkan konsep diri bahwa "aku bisa", sehingga anak akan lebih percaya diri dan bertanggung jawab. Selain hari memasak, Moeslichatoen (2004) juga mengungkapkan pentingnya kegiatan proyek yang memiliki manfaat seperti: memberikan pengalaman menyelesaikan masalah secara berkelompok (kerjasama), memberikan peluang bagi anak untuk mewujudkan daya kreativitasnya, dan mendorong munculnya pirbadi yang kooperatif/memiliki sikap positif (mandiri, tanggung jawab, saling membantu dan saling menghargai). Untuk hari karir, dapat menumbuhkan semangat anak untuk selalu belajar, percaya diri, dan menghargai profesi atau pekerjaan orang lain. Untuk hari pasar bertujuan untuk melatih jiwa 
kewirausahaan, kejujuran, kemampuan negosiasi, kemampuan komunikasi, dan melatih anak dalam berinteraksi dengan orang lain. Selain itu permainan kooperatif juga dapat melatih komunikasi dan kerjasama anak.

\section{Faktor Pendukung dan Penghambat Kegiatan}

Kegiatan pelatihanpengembangan metode pembelajaran untuk meningkatkan keterampilan sosial anak TKterlaksana berkat kerja sama antar anggota Tim PPM, adanya kerja sama dengan IGTK di wilayah kecamatan Adimulyo Kebumen, jajaran UPTD Kecamatan Adimulyo Kebumen dan antusiasme para guru TK di kecamatan Adimulyo Kebumen. Tempat serta fasilitas kegiatan didukung oleh UPTD Kecamatan Adimulyo dan IGTKI Adimulyoyang bekerja sama dengan Fakultas Ilmu Pendidikan UNY dalam hal ini diwakili oleh dosen PGPAUD FIP UNY selaku tim pelaksana kegiatan PPM. Pada pelaksanaan kegiatan pelatihan, ada beberapa hambatan yaitu kelas yang digunakan agak sempit sehingga membatasi gerak saat simulasi permainan. Secara keseluruhan, kegiatan dapat berjalan sesuai dengan agenda yang telah direncanakan.

\section{PENUTUP}

Pelatihan pengembangan metode pembelajaran dapat meningkatkan keterampilan sosial anak TK dapat menambah pengetahuan dan wawasan tentang keterampilan sosial dan ragam metode pengembangannya. Para peserta tampak antusias dan senang memperoleh materi tentang pengembangan metode pembelajaran untuk meningkatkan keterampilan sosial anak TK. Hal ini dapat dilihat dari hasil evaluasi penyelenggaraaan kegiatan dan evaluasi pengembangan metode pembelajaran yang telah mencapai indikator keberhasilan melebihi $80 \%$. Berdasarkan hasil penyebaran skala tentang penyelenggaraan kegiatan dapat disimpulkan bahwa $93 \%$ guru TK (61 peserta) merasa materi yang disampaikan sesuai dan bermanfaat. Hal ini dapat dilihat dari hasil pengisian skala yang rata-rata memperoleh skor 3 (kriteria baik). Untuk hasil pemberian tugas, enam kelompokmemperoleh kriteria baik dalam merancang kegiatan pembelajaran hari memasak, proyek, dan permainan kooperatif.Bagi guru sebaiknya dapat mengaplikasikan materi yang telah diperoleh dalam pelatihan ke dalam program pembelajaran di TK masingmasing.

\section{DAFTAR PUSTAKA}

Direktorat Pendidikan Tinggi. (2009). Kurikulum 2009. Peraturan Menteri Pendidikan Nasional tentang Kurikulum PAUD 2009. Jakarta: Dirjen Dikti

Majid, A. (2005). Perencanaan Pembelajaran: Mengembangkan Standar Kompetensi Guru. Bandung: PT Remaja Rosdakarya.

Moeslichatoen. (2004). Metode Pengajaran di Taman KanakKanak. Jakarta: Direktorat Jenderal Pendidikan Tinggi.

Sagala, S. (2003). Konsep dan Makna Pembelajaran: Untuk Membantu Memecahkan Problematika Belajar dan Mengajar. Bandung: Alfabeta.

Surakhmad, W..(1979). Metodologi Pengajaran Nasional. Bandung: Jemmars.

Keterampilan sosial. http://. wikipedia. keterampilan sosial anak. Diakses tanggal 20 Mei 2015 